\title{
Use of Reclaimed Rubber Cell in Highway Pavement: An Experimental Research
}

\author{
B. Manjula Devi, H.S. Chore
}

\begin{abstract}
With the rapidly growing number of vehicles around the world, the disposal of the waste and discarded tyres is a serious concern worldwide. There are few investigations reported in the literature w.r.t. the use of the regenerated rubber derived from the waste tyres in the construction of pavements. The highway construction forms a potential sector for the use of such waste whereby the problem of its disposal will get eliminated on one hand and reduce the environmental concern on the other hand. The use of such waste is found to improve the performance and strength of the pavement. This paper presents the limited experimental investigations on the use of innovative reinforcement in the form of rubber cell derived from the regenerated or reclaimed tyres in the pavement application. The rubber cell derived is similar to conventional geocell. The experimental study entails the use of the rubber cell placed within the conventional granular sub-base (GSB) of the conventional flexible pavement through a model pavement. The laboratory model tests were conducted with the help of the test tank of dimensions $(1 \mathrm{~m} \times 1 \mathrm{~m} \times 1 \mathrm{~m})$. The sub-base was placed above the weak subgrade in a test tank. The results of the laboratory model tests indicates the better performance of the pavement with the use of the rubber cell in the sub-base as compared to the performance of the pavement with conventional granular subbase without rubber cell reinforcement. The study confirms the effective utilization of the discarded tyres as a reinforcing material in the pavements.
\end{abstract}

Keywords - Flexible Pavement, Static Tests, Reclaimed Rubber cell Reinforcement

\section{INTRODUCTION}

Pavements are the essential features of the communication system and provide an efficient means of transportation of passengers, freights and other services necessary for the community. A flexible Pavement is a load bearing structure, consisting of the layers of different granular materials which are placed over the soil subgrade for forming the highways or airfield. The durability of such pavements depend upon various parameters such as strength of the subgrade soil, materials to be used in various layers of the pavement along with their quality, thickness of the layer and environmental conditions along with the traffic characterization. The pavement design aims at providing a structural and economical combination of materials to carry traffic in a given climate over the existing soil conditions for a specified time interval.

Marine clay is found widely along the coastal area and demands for the expensive solutions in the construction of coastal highways. Marine clay has a poor supporting capacity and experience large changes in its volume on

Revised Manuscript Received on April 12, 2019.

B. Manjula Devi, Research Scholar Department of Civil Engineering Datta Meghe College of Engineering Navi Mumbai-400708 (India) (mdevibala10@gmail.com)

H.S. Chore, Associate Professor Department of Civil Engineering National Institute of Technology Jalandhar-144011 India. (chorehs@nitj.ac.in) variations of moisture content. Therefore, such is required to be improved either by resorting to the ground improvement technique so as to render it suitable for road construction activities.

Rubber waste is generally obtained by the discarded tyres of the vehicles. According to the estimate pointed out by the Rubber Manufacturers' Association, in India around 200 250 million worn-out car tires are generated each year (JAWMA, 1990) .The world generates about 1.5 billon of waste tyre annually. With the rapidly growing number of vehicles around the world, the disposal of end-of-life tyres is serious issue. It poses an environmental concern. Therefore, it is necessary that such type of waste should be disposed off in the effective manner which would eliminate the problem of its disposal on one hand and reduce an environmental concern, on the other.

Owing to durability and flexibility, the rubber find an application in the highway construction. It can increase the pavement quality and improve the performance of the pavement. The discarded tyres are useful in the highway construction as a part of the reinforcement technique. At times, the rubber aggregates, may replace the natural aggregates partially in the pavement construction. With the large scale development taking place in the country in the highway and infrastructure sector and scarcity of the materials required for the construction as well as for the disposal of the tyre wastes, it can be used in this sector advantageously.

Re-generated or reclaimed rubber is produced by partial de-vulcanization of rubber granulate obtained from end-oflife tyres and other rubber products. It can be used as a substitute of natural and synthetic rubber. The major source of waste rubber is used automotive tyres. Mainly, two processes are involved in the utilization of these rubber tyres- first one is to convert the same the powder form which is used as filler and the second one is to devulcanize or reclaim the rubber powder.

The reclaimed rubber is primarily used in the manufacturing of the cycle tyres, rickshaw tyres, battery boxes, automobile tyres and other molded rubber goods; and further, research in this direction may lead to its use on the new frontiers. The price of reclaimed rubber is low as compared to the various types of synthetic or natural rubber. This makes it more competitive in the market. The use of the reclaimed rubber is not exploited fully and only $20 \%$ of the rubber scrap is being used in the reclaimation process. 


\section{LITERATURE REVIEW}

Use of waste tyres and plastic in conjunction with Pozzolanic materials has been dealt with by some of the researchers. Khan studied the performance of a road base constructed with shredded rubber tires[1]. Hassona evaluated shred tyre reinforced sandy soil. The presence of shredded waste tyres in sand was found to improve the strength of the sand [5]. Suat Akbulut studied the modification of clayey soils using scrap tire rubber and synthetic fibres[5]. Prasad demonstrated the improvement in the load carrying capacity of the model flexible pavement when the gravel sub-base of the pavement laid on expansive subgrade was reinforced with the waste plastics as well as the waste tyre rubber[15]. Subramanian and Jeyapriya studied the effect of waste tyres in the subgrade and subbase layers of the flexible pavement system and showed that the thickness of the pavement could be reduced with its use [17].

Bolden examined aspects of preparing construction materials based on recycled and industrial waste products[6]. Arunkumar investigated the suitability of materials such as ground granulated blast furnace slag and waste rubber tyre as replacement of coarse aggregates in place of conventional aggregates in sub-base layer and modified red soil is used as a filler material in sub-base layer[22].

The use of geosynthetics in the pavement structures have been dealt with by some of the researchers[7, 9, 10, 23].The studies revealed that the geosytthentics when incorporated at different locations serves more than one purpose, i.e., reinforcement, separation, drainage and filtration. It has also been observed that there could be reduction in the thickness of the pavement.

Earlier research (both laboratory and finite element) on Geocell was focused more on structure foundation (mostly building foundations) and less attention was given towards the use of geocell in pavement construction. Al-Qadi and Hughes evaluated the use of geocells in flexible pavements by conducting field studies[2]. The case selected was the reconstruction of a road that showed excessive rutting. The use of geocells was chosen as the solution on an experimental basis, and the results showed that the pavement laid on the confined base showed no signs of rutting. However, the study was unable to isolate effect of geocell alone, because of the the presence of other geosynthetics. Emersleben and Meyer conducted large scale model tests and field tests which showed similar results that verified the fact that geocells reduce surface deflections and vertical pressure on the subgrade. The tests also studied the effect of aspect ratio and results showed that performance improved with the increase in the height to diameter ratio. Emersleben and Meyer also conducted large scale model tests in test boxes measuring $2 \mathrm{~m} \times 2 \mathrm{~m} \times 2 \mathrm{~m}$. The tests showed that the surface deflection was less in a geocell confined section and the results were verified by FWD measurements carried out in field studies[4]

Although there is lot of work available in the literature in the context of the application of geosynthetics in the pavements, the studies pertaining to the use of grids and cell made up of from the discarded and waste tyres as a substitute to the conventional and commercially available geosynthetics is limited. In this study, an effort has been taken to evaluate the reclaimed rubber cell for pavement, on the lines similar to that of conventional geocell, on the performance of the pavement when the rubber cell is used in the sub-base.

\section{EXPERIMENTAL PROGRAMME}

Fig. 1 shows the model test tank and the loading arrangement which consist of a steel tank with inside dimensions of $1 \mathrm{~m} \times 1 \mathrm{~m} \times 1 \mathrm{~m}$ and braced with angle iron to avoid any yielding under the effect of the loading. The length and width of the tank is kept 5.8 times the size of steel plate of the loading plate and the height of fill is kept as 3.8 times the size of the steel plate of loading plate. Several other researchers $[8,9,14,21]$ have selected similar scaling for the model tanks to avoid the boundary effects.

A 15-mm thick rigid steel plate is used as a loading plate with the contact area of $170 \times 170 \mathrm{~mm}$. A spherical recess is made into the loading plate at its center to accommodate a steel ball of $20 \mathrm{~mm}$ diameter bearing through which vertical loads are applied to the plate by means of a strain-controlled hydraulic jack. It is driven by an AC drive controls $3 \mathrm{HP}$ electric motor supported against a $100 \mathrm{kN}$ reaction frame. The plate is pushed into the bed at a constant rate of 1 $\mathrm{mm} / \mathrm{min}$. The load value is measured through a pre calibrated $100 \mathrm{kN}$ capacity S type load cell placed between the ball bearing and the hydraulic jack. The loading plate is placed at the center of the tank to maintain the symmetry condition. Two dial gauges are used to measure the footing settlement in the GSB bed. Two dial gauges are placed at a diagonally opposite side of the centerline of the loading plate to measure its vertical settlement of reinforced and unreinforced GSB bed during loading. The settlement data reported here is the average of the readings taken at two.

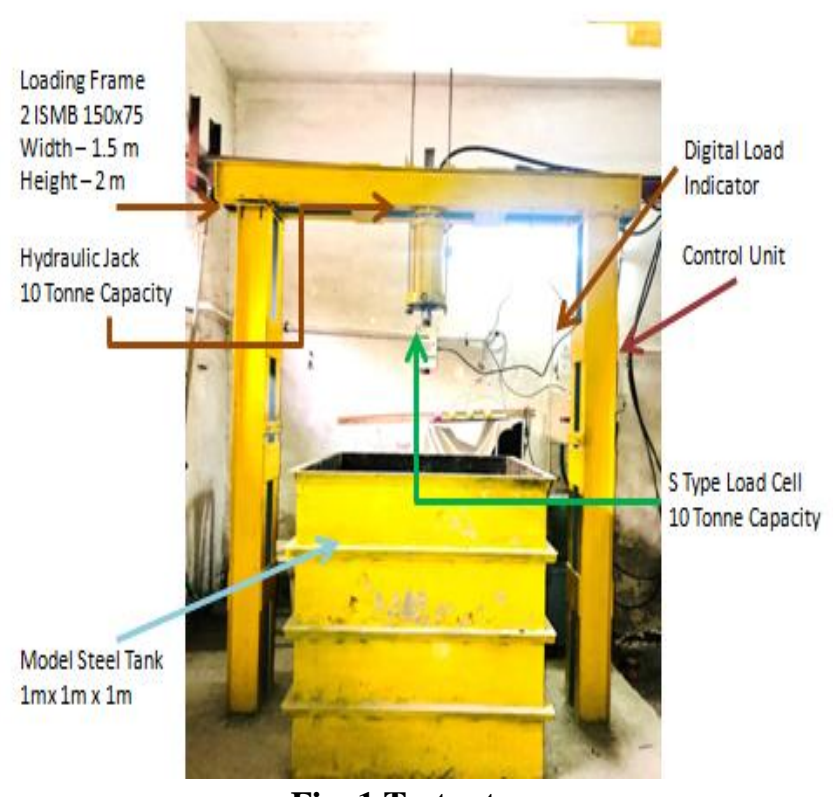

Fig. 1 Test set up 


\section{MATERIALS}

The materials used in the experimental studies include subgrade soil (Marine clay), Granular sub-base materials, Geotextile and Reclaimed Rubber cell .

\section{Subgrade Soil}

The subgrade soil used in the present investigation is the Marine Clay. It was collected from the JNPT (Jawaharlal Nehru Port Trust) Mumbai, Maharashtra State, India by approximately $50 \mathrm{~m}-60 \mathrm{~m}$ from the banks of the Uran Creek at a depth of $3-3.5 \mathrm{~m}$. The location of the site in Google map is shown Fig.2.

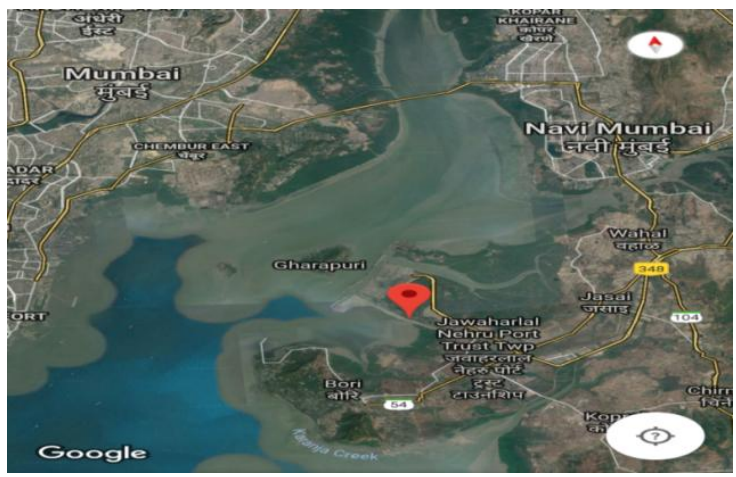

Fig. 2. Site location

The properties of the subgrade soil were evaluated following systematic laboratory investigation and are summarized in Table 1.

Table 1 Physical properties of soil sample

\begin{tabular}{|c|c|c|}
\hline Sr. No. & Parameters & Value \\
\hline 1 & Specific gravity & 2.45 \\
\hline 2 & Liquid limit (\%) & 77 \\
\hline 3 & Plastic limit (\%) & 35 \\
\hline 4 & Sand (\%) & 3.90 \\
\hline 5 & Silt + Clay (\%) & 96.10 \\
\hline 6 & Soil Classification & CH \\
\hline 7 & Soil specification as per & A-7- \\
& AASHTO & $5(24)$ \\
\hline 8 & Optimum moisture content (\%) & 31 \\
\hline 9. & Maximum dry unit weight & 13.73 \\
\hline 10. & (kN/m $^{3}$ ) & 0.784 \\
\hline 11. & Void ratio (e) & 4.54 \\
\hline 12. & California Bearing ratio (CBR) & 23.045 \\
\hline
\end{tabular}

\section{Granular sub-base}

Aggregates of different size ranges were sampled such that it conformed to Gradation I as specified by MoRTH . The granular sub-base had a maximum dry unit weight of $22.1 \mathrm{kN} / \mathrm{m} 3$ corresponding to the water content of $6.2 \%$. The CBR of gradation is $45 \%$ which is satisfying the MoRTH requirements. The grain size distribution curve of the granular sub-base used in the experiments is shown in Fig. 3.

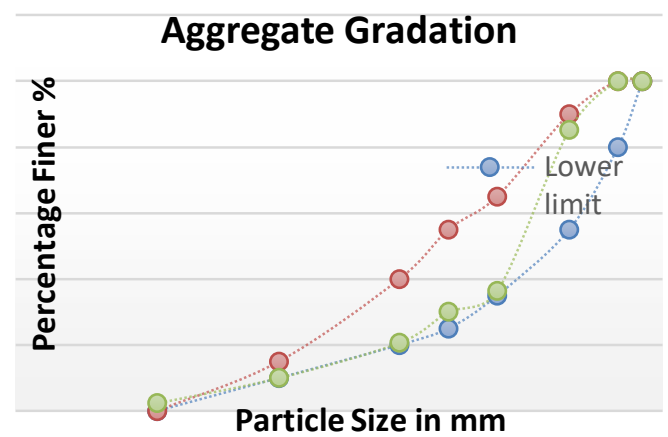

Fig.3.Grain size distribution curve of the granular subbase materials

\section{Geotextile}

Readymade nonwoven geotextile was placed at the interface of subgrade and sub-base course as separator in all the cases. The Properties of the Geotextile used in the tests are summarized in Table 2. These properties have been provided by the supplier.

Table 1 Properties of the geotextiles used

\begin{tabular}{|c|c|c|c|c|}
\hline $\begin{array}{c}\text { Sr. } \\
\text { No. }\end{array}$ & Test & Unit & $\begin{array}{c}\text { ASTM } \\
\text { Method }\end{array}$ & Result \\
\hline 1. & Thickness & $\mathrm{Mm}$ & $\mathrm{D}-5199$ & 1.84 \\
\hline 2. & $\begin{array}{c}\text { Grab Strength } \\
\text { MD/ CD }\end{array}$ & $\mathrm{N}$ & $\mathrm{D}-4632$ & $729 ? 881$ \\
\hline 3. & $\begin{array}{c}\text { Elongation @ } \\
\text { break MD/CD }\end{array}$ & $\%$ & $\mathrm{D}-4632$ & $66.5 / 72.4$ \\
\hline 4. & Trapezoidal tear & $\mathrm{N}$ & $\mathrm{D}-4533$ & 332 \\
\hline 5. & $\begin{array}{c}\text { Puncture } \\
\text { strength }\end{array}$ & $\mathrm{N}$ & $\mathrm{D}-4833$ & 444 \\
\hline 6. & Water flow & $1 \mathrm{sqm} / \mathrm{sec}$ & $\mathrm{D}-4491$ & 85 \\
\hline 7. & Permittivity & $\mathrm{S} 4$ & $\mathrm{D}-4491$ & 1.7 \\
\hline 9. & Mullen burst & $\mathrm{kPa}$ & $\mathrm{D}-3786$ & 2285 \\
\hline
\end{tabular}

\section{Rubber Cell}

The cells were are made of reclaimed rubber with a wall thickness of $2 \mathrm{~mm}$. The expanded cell dimensions are length $100 \mathrm{~mm}$, width $80 \mathrm{~mm}$ and the depth $100 \mathrm{~mm}$. These cells are similar to the conventional geocell. The plastic tie wires were used for joints to form the cell mattress. The rubber cell used in the study is shown in Fig. 4.

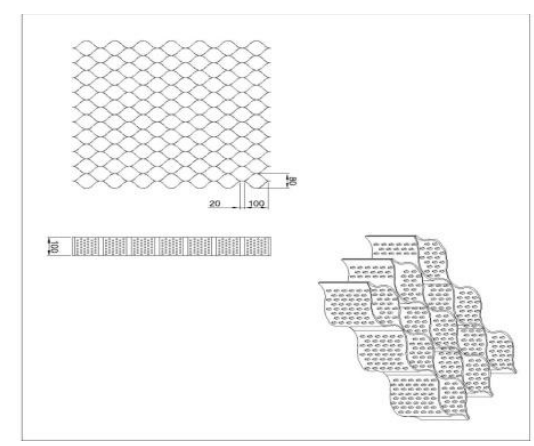

Fig.4. Schematic sketch of the reclaimed rubber cell 


\section{SAMPLE PREPARATION}

Subgrade

The clayey soil was first pulverized and then mixed with a predetermined amount of water. To attain uniform moisture content, the wet soil was covered by plastic sheet for about 48 hours. Before filling the test tank with clay, the lubricant was applied to minimize the wall friction. The marine clay was filled in the model tank in 5 layers, each layer being $10 \mathrm{~cm}$ height up to $50 \mathrm{~cm}$. By carefully controlling the compaction effort and the water content of the test bed, a uniform density of test bed was maintained. Undisturbed samples were collected at different locations of the test bed to determine the unit weight, moisture content and the unconfined compression strength (UCS) of soil. The results at different locations of the clay bed are found to be in good agreement satisfying the uniformity of the clay bed. The properties of the clay bed are summarized in Table 3.2 and the same properties were maintained in all the tests. Table 3. Represents the properties of clay bed.

Table 3. Properties of clay bed

\begin{tabular}{|l|l|l|}
\hline Sr. & \multicolumn{1}{|c|}{ Parameters } & \multicolumn{1}{|c|}{ Value } \\
\hline 1. & Moisture content $(\%)$ & 50 \\
\hline 2. & Dry unit weight $\left(\mathrm{kN} / \mathrm{m}^{3}\right)$ & 10.78 \\
\hline 3. & Void ratio(e) & 1.27 \\
\hline 4. & California Bearing Ratio (CBR) \% & 1.19 \\
\hline 5. & UCS $\left(\mathrm{kN} / \mathrm{m}^{2}\right)$ & 4.01 \\
\hline
\end{tabular}

Holtz suggested that the optimum use of geosynthetics in roadway construction in the context of CBR of the subgrade soil being less than $3 \%$ [24]. In the particular marine clay soil, the CBR value at OMC is found to be $4.45 \%$. Therefore, the subgrade CBR of $50 \%$ was chosen in order to evaluate the benefit of rubber cell reinforcement to improve the performance of bases over weak subgrade.

\section{Un reinforced Sub base}

The Granular sub-base bed was prepared at its OMC. A non-woven geotextile was placed between the clay layer (subgrade) and the sub-base for separation and filtration purpose. The sub base layers were compacted above the subgrade layer, each layer being of thickness of $50 \mathrm{~mm}$ and the total thickness being $150 \mathrm{~mm}$.

The water content of the granular sub-base was maintained as $6.2 \pm 0.5 \%$. The dry unit weight achieved by the granular sub-base layer was $21.01 \pm 0.5 \mathrm{kN} / \mathrm{m} 3$.

\section{Reinforced Sub-base}

While preparing the Reclaimed rubber cell-reinforced Granular sub-base bed, a nonwoven geotextile was always placed as a separator over the clay bed (subgrade). To prepare the reinforced GSB bed, the rubbercell was placed in the tank and it was stretched from ends to adjust its position and filled with GSB materials in equal layers as same in case of unreinforced bed with uniform compaction by means of a specially fabricated steel rammer of $15 \mathrm{~mm}$ diameter. With this compaction effort, $94 \%$ of the maximum dry density was achieved. The care was exercised not to fill any cell to the total height until the adjacent cell was at least filled to half of the height. This was done to ensure the proper shape of the cell layer with aggregate infill. Fig. 5 and 6 shows photographs of rubber cell- reinforced GSB bed in its preparation stage

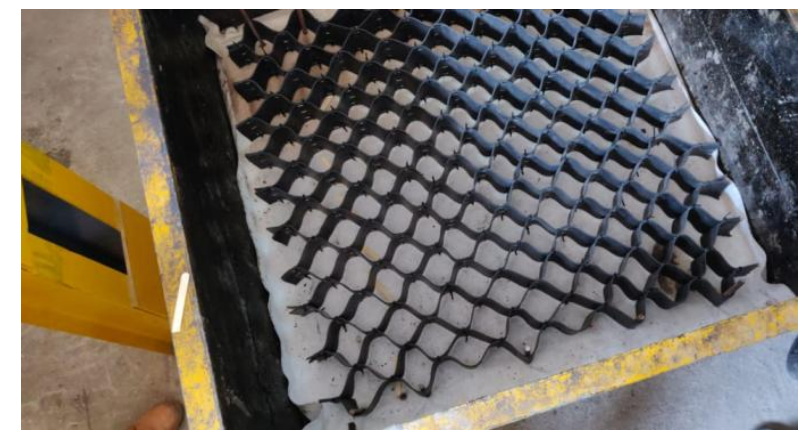

Fig. 5. Expanded Rubber cell installed on the Geotextile over subgrade

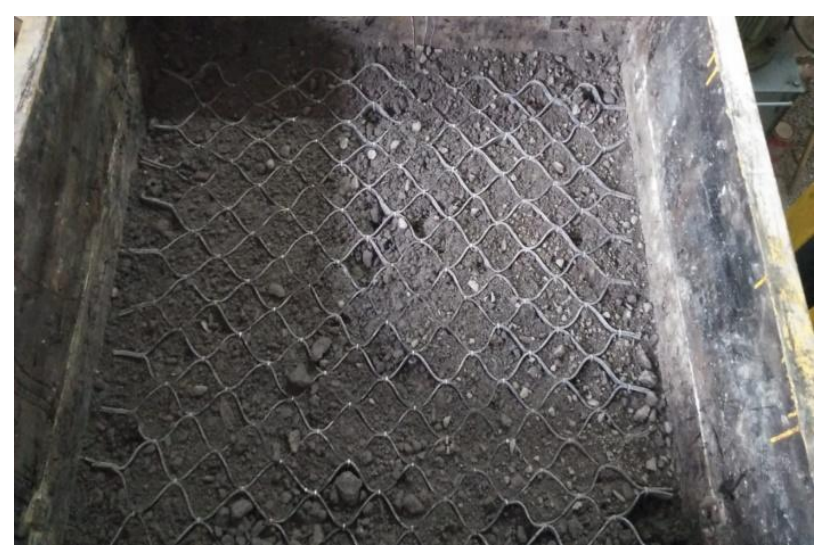

Fig.6. Filling GSB materials in rubber cell

\section{EXPERIMENTAL PROCEDURE}

After preparation of the clay bed, the test sections were instrumented with load cell and dial gauges. The resistance offered by the sections was measured using a load cell and the vertical deformation was measured using dial gauges. The load was applied by the hydraulic jack which was driven by an AC drive controls $3 \mathrm{HP}$ electric motor. The application of the load to the prepared bed continued at constant speed of $1 \mathrm{~mm} / \mathrm{min}$ and the load was read and noted every minute. This test was carried out on marine clay, unreinforced GSB bed and reclaimed Rubber cell reinforced bed.

\section{RESULTS AND DISCUSSION}

The primary objective of the experimental investigation is to assess the efficacy of the reinforcement in the form of the reclaimed rubber cell on the performance of the pavement when the reinforcement is provided within the sub-base course. For this purpose, the strain-controlled model tests (in static condition) were carried out on the model pavement w.r.t. two conditions- the first one is unreinforced granular sub-base layer placed on the marine clay subgrade and the second one, granular sub-base containing recycled rubber cell. In either case, the non-woven geotextile was placed at the interface of subgrade and sub-base. 
For evaluating the strength of the pavement for the forementioned conditions, the load deformation behavior was studied. The observations from the tests were noted and the load-deformation curves were plotted. Fig. 8 shows the load- deformation characteristics in respect of the present study.

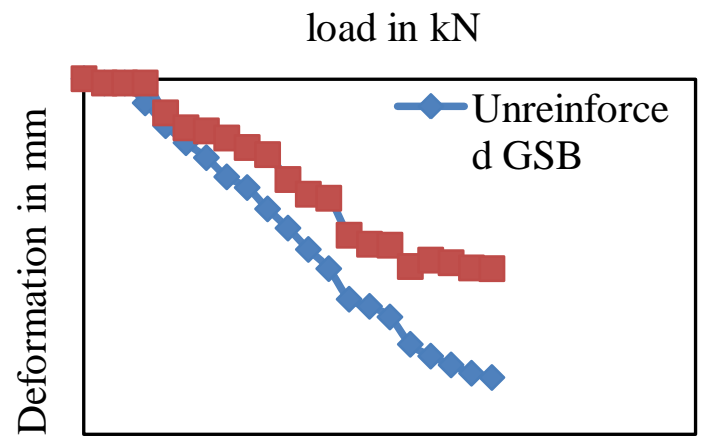

Fig 8. Load - displacement relationship for model flexible pavements

The result indicates that at the initial application of the load, not much difference is seen in the deformation behavior of the pavement in the context of unreinforced subbase and reinforced sub-base. However, with the increase in the load further, the deformation of the pavement is found to be less with respect to the sub-base reinforced with rubber cell derived in the study as compared to that in case of the pavement with unreinforced sub-base.The difference between the deformation is also observed to increase with increase in the load.

Further, the load carrying capacity of the model pavement is found to increase by $30 \%$ approximately with the introduction of the reclaimed rubber cell within the sub-base of the model pavement.

When compared with some of the literature reporting the use of the geocell in the sub-base, it is seen that the reinforecement derived in the present study and that similar to the geocell is found to perform in the similar manner, rather better than the conventional geocell.

Notwithstanding, the reports presented in this paper are based on the initial phase of the present investigations. For studying the more precise performance of the reinforcement derived as a part of the investigation, more number of trials with various parameters of the reinforcements, materials to be used in various layers (especially the use of Pozzolanic materials), etc. is necessary. The quantitative results from the present study are based on small-scale model test with single cell height .To justify the results tests on different cell height and field tests are required.

\section{SUMMARY AND CONCLUSIONS}

Based on the limited experimental investigations carried out on the reclaimed rubber cell reinforced model pavement, it can be deduced that the use of reclaimed rubber cell within the sub-base of the pavement increases the load carrying capacity of the pavement and reduce the settlement.

The use of such waste materials in the pavement will not only provide viable solution to its disposal which otherwise would rresult into an environmental concern, but also effective utilization of such material as the sustainable construction material in the field of road development.
Moreover, the construction of pavement would also be economical. For the developing the country like ours, this assumes the significance

\section{REFERENCES}

1. A.Suat, A.Seracettin, and K.Ekrem,"Modification of clayey soils using scrap tire rubber and synthetic fibers", in Elsevier, Applied Clay Science ,2007, PP 23-32.

2. I.L.Al-Qadi, and Hughes, J. J., "Field evaluation of geocell use in flexible pavements". Transportation Research Record (TRB) H. 1709, S. $26-35,2000$.

3. C. S. Poon, and D. Chan, "Feasible use of recycled concrete aggregates and crushed clay brick as unbound road sub-base", in Elsevier, Construction and Building Materials 20 ,578585,2006 .

4. A.Emersleben and N.Meyer, "The use of geocells in road constructions - falling weight deflectometer and vertical stress measurements". EuroGeo4, Paper no. 132. Proceedings of the 4th European Geosynthetics Conference, Edinburgh, Scotland 2008.

5. Hassona, Hassan, Marei, and Hashem, "Triaxial test and CBR test on shred tyre reinforced soil, concluded that The presence of shredded waste tyres"-2005.

6. J.Bolden, T.Abu-Lebdeh and E.Fini , "Utilization of recycled and waste materials in various construction applications", American Journal of Environmental Science, 9 (1), 14 24,2013.

7. A.M.Khalid, and Eyad A.H., "Geo-textile in transportation applications", Paper presented at the Second Gulf Conference, 2004.

8. J.Leng,, "Characteristics and behavior of geogrid-reinforced aggregate under cyclic load," North Carolina State University, Raleigh: 152 pp,2003.

9. M. N. Asha and G. Madhavi Latha," Model Studies on Geocell Reinforced Granular Sub-bases" Ground Improvement and Geosynthetics GSP 238 C ASCE 2014,pp $322-32$.

10. S.Maxwell,"Effectiveness of Geosynthetics in Stabilizing Soft Subgrades", Wisconsin,United States of America,2005.

11. MORTH-2001: Specifications for Roads and Bridge Works, Ministry of Road Transportation and Highways, Govt. of India

12. P.Kumar, and Rathish, "Mechanical properties of Fiber reinforced concretes produced from building demolished waste", international journal of environmental research and development, Vol. 2, No.2,pp: 180-187,2007

13. P.V.V. Satyanarayana ,"A Study on the Performance of Crusher Dust In Place Of Sand and Red Soil as A Subgrade And Fill Material" IOSR Journal of Mechanical and Civil Engineering (IOSR-JMCE), Volume 9, Issue 2, 53-57,2013.

14. S.W. Perkins, "Mechanical response of geosyntheticreinforced flexible pavements." Geosynthetics International, Vol. 6(5): 347-382,1999.

15. Prasad, R.Prasada, M.Ramana, 'Use of Waste Plastic and Tyre in Pavement Systems', IE(I) Journal-CV, Vol.89, pp 31-35,2008.

16. R. A. Khan and A. Shalaby, "Performance Of A Road Base Constructed With Shredded Rubber Tires" Annual Conference of the Canadian Society for Civil Engineering PP 1-10 Montréal, Québec, Canada,2002.

17. R. M. Subramanian and S. P. Jeyapriya, "Effect of Waste Tyres in Flexible Pavement System", in Indian geotechnical society Chennai chapter, student's paper competition, 2009.

Published By: Blue Eyes Intelligence Engineering 
18. S.K.Shukla, Handbook of Geosynthetic Engineering: Geosynthetic applications - general aspects and selected case studies. Edith Cowan University, Perth, Australia. First edition. Shukla, S. K. editor. ICE Publishing, UK, London, pp.365-385,2012.

19. Sitharam, T.G, Sireesh, S., and Dash, S.K,Performance of surface footing on geocell-reinforced soft clay beds. Geotechnical and Geological Engineering, 25: 509-524,2007

20. T.Bennert, and A.Maher, " The Development of a Performance Specification for Granular Base and Subbase Material”. Report No. FHWA-NJ-2005-003, pp. 55, 2005.

21. J.K.Thakur, J.Han,S.K.Pokharel, and R.L.Parsons,"Performance of geocell- reinforced recycled asphalt pavement (RAP) bases over weak subgrade under cyclic plate loading" Geotextiles and Geomembranes, 35, 14$24,2012$.

22. U.Arun Kumar and P.V.V.Satyanarayana, " A Comparative Study on Utilization of Waste Materials in GSB Layer" SSRG International Journal of Civil Engineering (SSRG-IJCE) volume1 issue 3 August 2014

23. J.S. Vinod ,B.Indraratna, and A. Moghaddam, Behaviour of geocell reinforced foundation undre cyclic loding, Proceedings of Indian Geotechnical Conference December 15-17,2011, Kochi (Paper No.J-122),2011.

24. R.D.Holtz, B.R.Christopher,R.B.Berg, "Geosynthetic Design and Construction Guidelines. National Institute of Highway" Publication No. FHWA NHI-07e092, 612 p,2008. 